\title{
THE PROJECTIVE THEORY OF CONSCIOUSNESS: FROM NEUROSCIENCE TO PHILOSOPHICAL PSYCHOLOGY
}

\author{
Alfredo Pereira Jr. ${ }^{1}$
}

\begin{abstract}
The development of the interdisciplinary areas of cognitive, affective and action neurosciences contributes to the identification of neurobiological bases of conscious experience. The structure of consciousness was philosophically conceived a century ago (HUSSERL, 1913) as consisting of a subjective pole, the bearer of experiences, and an objective pole composed of experienced contents. In more recent formulations, Nagel (1974) refers to a "point of view", in which qualitative experiences are anchored, while Velmans $(1990,1993,2009,2017)$ understands that phenomenal content is composed of mental representations "projected" to the space external to the brains that construct them. In Freudian psychology, the conscious mind contains a tension between the Id and the Ego (FREUD, 1913). How to relate this bipolar structure with the results of neuroscience? I propose the notion of projection [also used by Williford et al. (2012)] as a bridge principle connecting the neurobiological systems of knowing, feeling and acting with the bipolar structure. The projective process is considered responsible for the generation of the sense of self and the sense of the world, composing an informational phenomenal field generated by the nervous system and experienced in the first-person perspective. After presenting the projective hypothesis, I discuss its philosophical status, relating it to the phenomenal (BLOCK, 1995, 2008, 2011) and high-order thought (ROSENTHAL, 2006; BROWN, 2014) approaches, and a mathematical model of projection (RUDRAUF et al., 2017). Eight ways of testing the status of the projective hypothesis are briefly mentioned.
\end{abstract}

Keywords: Projection. Consciousness. Cognitive. Non-Conceptual. Feeling.

\section{INTRODUCTION}

The interdisciplinary effort of building a theory of consciousness is a central feature of contemporary philosophical and scientific scenario. Several authors, including Edelman (1989), Crick (1994), Block (1995), and Damásio (2000), have proposed the existence of different types of consciousness, while other authors, including Tononi [see Tononi et al. (2016)], Koch (2003), ${ }^{1}$ Professor at São Paulo State University (Unesp), Botucatu, SP - Brasil. E-mail: alfredo.pereira@
unesp.br

http://dx.doi.org/10.1590/0101-3173.2018.v41esp.11.p199

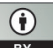

This is an open-access article distributed under the terms of the Creative Commons Attribution License. 
and Dehaene and Changeux (2013), have addressed the neural correlates of conscious activity.

Equally important for the epistemological foundation of a science of consciousness is the identification of the psychological features of conscious activity (NAGEL, 1974; VELMANS, 2009; HARNAD, 2011; NORTHOFF, 2016), focusing on the triad of conscious mental functions: cognitive (BAARS, 1988), affective (PANKSEPP, 1996; BARRETT; RUSSELL, 1998; BARRETT, 2017) and enactive or action-related (JEANNEROD, 1998), as well as an adequate treatment of the degrees of phenomenal consciousness putatively present in different biological species (CARRARA-AUGUSTENBORG; PEREIRA JR., 2012).

In contemporary philosophy, the presentational reality of lived experience has been variously referred as the lifeworld (HUSSERL, 1947), and addressed with existential categories as care and angst (HEIDDEGER, 1962), pre-reflexive experience (MERLEAU-PONTY, 1945) and forms of life (WITTGENSTEIN, 1969), while the classical Cartesian thinking substance is replaced by experiential concepts (for instance, the minimal self discussed by Zahavi, 2017).

Non-reductionist approaches face the challenge of relating the activity of the nervous system - and its extension in psycho-neuro-immuno-endochrine pathways, interacting with the physical, biological and social environment with the phenomenal experience of organisms that is accessible only to the first-person perspective (NAGEL, 1974). This challenge gave rise to the field of neurophenomenology, containing different philosophical views about the nature of the brain and conscious experience, and their relations (VARELA, 1996).

Two central psychological features of conscious experience are the subjective "point of view" (NAGEL, 1974), the bearer of qualitative experiences ("what it is like to be"), and the location of perceived objects and processes outside the brain, or "perceptual projection" (VELMANS, 1990, 1993, 2009, 2017). These aspects are common and almost obvious in our conscious lived experiences, but very hard to explain neuroscientifically.

The development of neuroscience and psychology in the "brain decade" (1990-2000) gave rise to the interdisciplinary areas of cognitive, affective and action neurosciences, advancing in the task of elucidating the dynamic structure of conscious activity. This structure was philosophically conceived a 
century ago as consisting of a subjective pole capable of experiencing, and an objective pole composed of the experienced contents (HUSSERL, 1913). In Freudian psychoanalysis, the structure of the conscious mind was conceived as a interplay between the Id and the Ego (FREUD, 1913). Morsella (2005) understands that consciousness involves a tension between subjective desires and objective needs. How to relate this bipolar structure to the results of neuroscience?

The conventional way of addressing this problem is to identify the cerebral correlates of subjective desires and objective constraints. In McLean's (1986) triune brain model, primitive impulses relate to the "reptilian brain," emotions with the "limbic system," and logical-rational-moral thinking with the functions of the neocortex, centred on pre-frontal circuits.

The distinction of the limbic system as an emotional center, and the associative cortex (in the human species, especially the prefrontal cortex) as the seat of reason and self-consciousness, is common in neuropsychology [see Stuss et al. (1994)]. A popular distinction, but without conclusive neuroscientific support, concerns hemispheric specialization: the right hemisphere would be "more emotional" and the left hemisphere "more rational."

Alternatively, a recent approach based on neuro-astroglial interactions relates feeling with hydro-ionic waves in living tissue and cognition with axonal action potentials (partially) isolated from those waves by myelin [see Rocha, Pereira Jr. and Coutinho (2001), Rocha, Massad and Pereira Jr. (2005), Pereira Jr. and Furlan (2009, 2010), Pereira Jr. (2007, 2012, 2013, 2014, 2015a, b, 2017), Pereira Jr. et al. (2013, 2015, 2016, 2017 and 2018)]. In this approach, there are two types of signal processing in the brain: one based on continuous hydro-ionic waves in living nervous tissue, corresponding to feelings, and the other based on discrete electrical pulses through axons isolated by a myelin layer, corresponding to the processes of sensory transmission, mental representation, logical thinking and motor control. Ionic waves in the nervous tissues and axonal pulses in the neural networks interact intimately; graded neuronal potentials generate waves, and these waves modulate synapses, reinforcing or depressing the frequency of action potentials.

Here I make a theoretical synthesis aimed to promote an interdisciplinary integration of philosophical psychology with neuroscience. The concept of projection, based on the work of Max Velmans (1990, 1993, 2009, 2017) 
and discussed by Willford et al. (2011) and Rudrauf et al. (2017), is used as a "bridge" between neuroscience and philosophical psychology.

The conceptual progress achieved with this formulation leads to other questions: How to explain the projection operation? How to scientifically test hypotheses in this regard? The existence of projective operations was inferred on the basis of psychophysical, phenomenological, and related considerations within philosophical psychology, but investigation of the neurobiological bases of intero- and exteroceptive projection requires interdisciplinary approaches to support conjectures about the structures and functions underlying them.

The test of the projective hypothesis can be made in several areas of investigation and therapeutic practices, namely: neurophenomenology; systematic introspection; meditation; hypnosis; brain stimulation; psychopharmacology, psychoanalysis and psychophysics. I briefly indicate how each of these methods of investigation and/or therapeutic practices could contribute to elucidate the status of the projective process.

\section{Departing From the NeUROSCIENCES}

Human conscious activity consists of three sets of mental functions, addressed by the respective branches of neurosciences:

2.1) Cognitive neuroscience addresses the knowing function, which is supported mainly by neocortical neural circuits, in particular by the triangulation of associative areas: parietal, temporal and pre-frontal. This function is composed of several sub-functions (perception, learning, memory, attention, logical-mathematical thinking, planning, moral judgment, decision making, as covered in the chapters of the classic work edited by Gazzaniga, 1993);

2.2) Affective neuroscience deals with the feeling function, supported mainly by subcortical structures such as the gray periaqueductal area (PANKSEPP, 1998), the limbic system (including glia and other tissue components), insula, somatosensory cortex, central nervous system connections with the enteric and cardiac nervous systems, and also with the endocrine and immune systems. I use the term feeling from (DAMASIO, 2000) to refer to the conscious experience of all types of sensation and emotions;

2.3) Neuroscience of action addresses the acting (or open behavior) function, which is supported by the motor system, including the pre-motor 
and motor cortices, cerebellum, basal ganglia, vestibular system, connections with sensory areas responsible for "corollary discharge" (WURTZ, 2013), pyramidal axonal connections with neuro-muscular junctions, sensors and muscle effector mechanisms involved in movement and kinesthetic perception (JEANNEROD, 1997).

The approach to conscious experience arising from the combination of the three branches of neurosciences, focusing on knowing, feeling and acting, is illustrated in Figure 1:

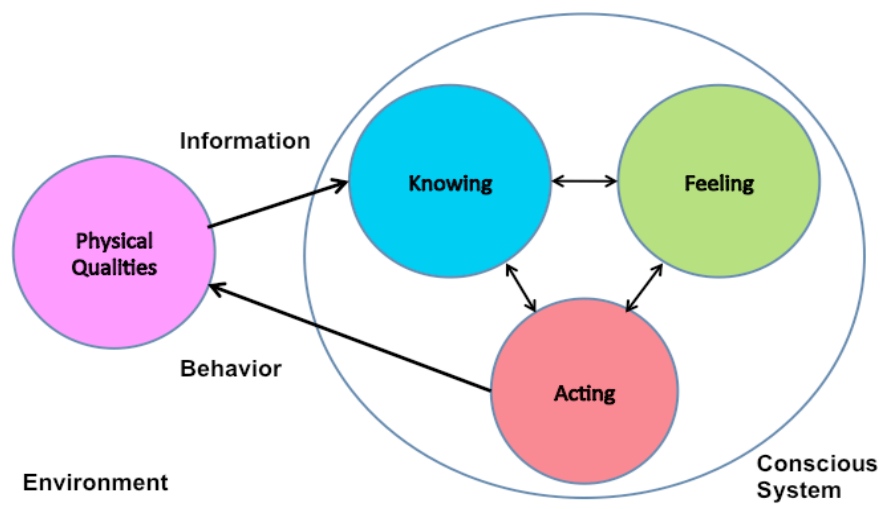

Figure 1: Conscious system. The conscious system system is an open and dynamic one, interacting with the environment. It is composed of three functions: knowing, feeling and acting. Human consciousness is dynamically constituted by the interactions between the three functions in time cycles [a first version of this type of diagram was published in Pereira Jr. et al. (2013)].

\section{THE PROJECTION HYPOTHESIS}

Two approaches in philosophical psychology have helped researchers to address the features of phenomenal experience. First I cite the distinction between first and third-person types of knowledge (NAGEL, 1974). Nagel proposes: "Every subjective phenomenon is essentially connected with a single point of view." (NAGEL, 1974, p. 437). However, the subjective point of view is not to be conceived in terms of a substance or soul, in the Cartesian tradition, but as derived from natural experiences and their supporting biological mechanisms, as in his example of an animal (the bat) using echolocation (a biophysical perceptual apparatus). 
Conscious experiences of an organism can be referred to a point of view, constituting the first-person perspective. The same reasoning can be applied to objective phenomena, for which the third-person perspective is adequate:

In speaking of the move from subjective to objective characterization, I wish to remain noncommittal about the existence of an end point, the completely objective intrinsic nature of the thing, which one might or might not be able to reach. It may be more accurate to think of objectivity as a direction in which the understanding can travel. (NAGEL, 1974, p. 443).

From this quote it is clear that the third-person perspective was conceived by Nagel as a directionality of understanding implying some type of projective process. This directionality is closely related to philosophical concepts such as the "aboutness" [for a review, see Bourget and Mendelovici (2017)] and the "transparency" of mental representations (TYE, 1996, 2002).

Velmans (2012) offers a similar account, in a clarifying footnote:

Although I have borrowed the term 'the thing itself' from Kant [...] this is not an unknowable thing-itself (an aspect of Kant's thought that has been found problematic even by many Kantians). If human knowledge is one manifestation of a wider reflexive process by which the universe itself comes to know itself, there is ultimately no separation between knower and known, and knowledge becomes a form of self-knowledge. Kant was of course right to stress that human knowledge is constrained by the ways that human perceptual and cognitive systems operate and cannot therefore provide observer-free knowledge of the world as it is in itself. Consequently it may not be possible for the embodied human mind to fully know the nature of its own ground of being. That does not, however, rule out partial, uncertain, species-specific knowledge [...] that is entirely conventional in science.

The third-person perspective of science is a special type of intersubjective agreement (VELMANS, 2009) based on methodological constraints and empirical/experimental testing of hypotheses, leading to what Nagel (1986) called "the view from nowhere". Knowledge about conscious experiences derives from first-person experiences, or "what it is like to be" a conscious experiencer, which provides what Varela and Shear (1999) called "the view from within". 
The second approach I cite is the discussion of projection by Velmans. How can we relate the phenomenal space of subjective experiences to the physical space objectively described in science? A scientific approach is found in psychophysics, by comparing subjective evaluations of spatial properties (such as distance, length) with objective measures (VELMANS, 2009). We know from neuroscience that conscious perception requires the processing of signals in the nervous system, and the representation of the characteristics of the perceived objects in the brain; for instance, in visual perception a twodimensional retinotopic image of a perceived object is formed in the occipital primary visual area, by means of a pattern of activation of columns of neurons. However, when this image is consciously perceived, the represented object is experienced as being located "out there in the world" external to the brain. How is this experience possible?

Velmans (1990, 1993) assumes the existence of information processing from a stimulus external to the brain to the central nervous system, where a representation of properties of the stimulus is formed. However, the conscious experience of the properties of the stimulus is not referred to brain activity, but somehow projected to the location of the stimulus, as shown in Figure 2:

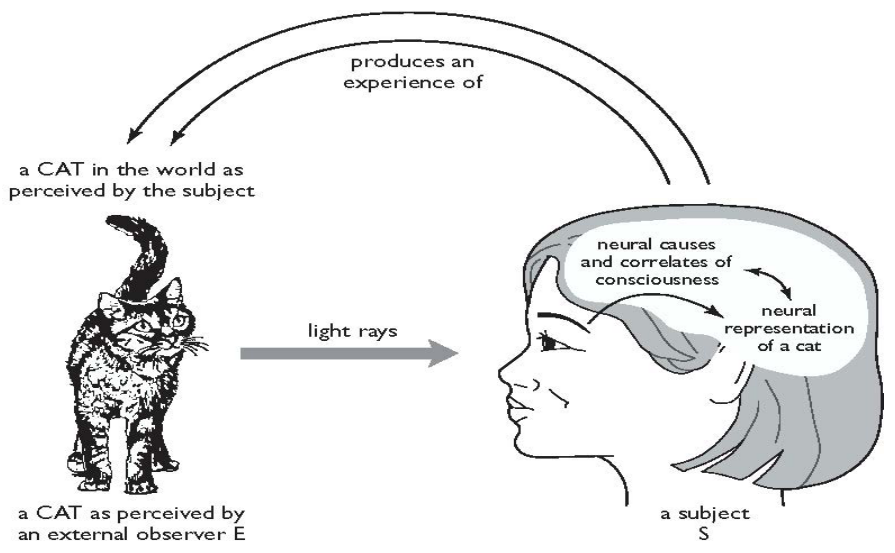

Figure 2: Perceptual projection. A conscious subject receives light ray signals from an external stimulus (a cat); she forms a neural representation of the animal in her brain, and then the neural causes/correlates of consciousness produce an experience of the cat-in-theworld; how is this projection possible? Figure by Velmans (2017), used with permission. 
Velmans' (1990, 1993, 2009, 2012, 2017) discussion of perceptual projection can be summarized in three sentences:

1) We perceive objects and processes by means of the formation of neural representations in our brains, but

2) The lived experience we have of physical objects and processes implies that they are located "out there", in the experiential physical space; therefore,

3) We "project" our neural representations into the experiential physical space in such a way that conscious experience is not of a solipsistic kind (it is not "locked" in the brain), but somehow "reflects" reality.

One attempted explanation of perceptual projection is in terms of the concept of information. Phenomenal and correlated neurophysiological spaces are thought to have the same informational structure: "(The) mind can be thought of as a form of information processing." (VELMANS, 2012). Considering the first person phenomenology of a subject $S$ and their neural correlates (viewable from the third-person perspective of an external observer $\mathrm{E})$, he claims that

the information structure of what $\mathrm{S}$ and $\mathrm{E}$ observe is identical, but it is displayed or "formatted" in very different ways [...] the information displayed in experiences and their physical correlates can be thought of as two manifestations of this information processing [...] the nature of mind is not either physical or conscious experience; it is at once physical and conscious experience. For lack of a better term we may describe this nature as psychophysical. (VELMANS, 2012).

The bipolar structure of consciousness can be conceived as a phenomenal informational field composed of a subjective pole (the sense of self) and an objective pole (the sense of the world). This field, according to my hypothesis, is constructed by means of a projection of neural activity; being experienced in the perspective of the first person (NAGEL, 1974), that is, by the individual who projects it. It is possible to conceive Nagel's concept of "point of view" as a projective operation, in this case an inwardly directed one, while perceptual projection goes in the outward direction. In this approach, not only the sense of the world, but also the sense of self, or "point of view" (NAGEL, 1974) are considered as resulting from projective operations; the sense of self is constituted 
by an introceptive projection, while the sense of the world is constituted by a perceptual projection following the exteroceptive direction.

The subjective pole, or sense of self, is conceived as the "attractor" in the dynamics of sensory, emotional and affective systems of the living body. The attractor state is generated in the feeling history of the individual, and projected as an invariant "identity" in time; the result of this projection is the sense of self [as further elaborated and discussed in Reddy et al. (2019)].

The objective pole, or sense of the world, is the projection of representations from the nervous system to its extensions related to the homeostasis and control of the body, which include neuro-muscular junctions, kinesthetic sensors in muscles, the cardiac and enteric nervous systems [for a discussion of the possible effect of emotions in the psycho-neuro-endocrineimmune system, see Pregnolato, Damiani and Pereira Jr. (2017)]. Feedback cycles between the central nervous system and the extra-cerebral structures of the motor system can give rise to the sense of the world, in which the world is understood as an "intensional object", not as a "thing in itself".

In neurobiological terms, such a projection is made from the centre to the periphery of the nervous system, forming the "egocentric space" (TREHUB, 1991), in which the agent who experiences the contents is at the centre, defining a proximal space, and the external world is situated at the distal end, as a field of perception and action. This informational field, which is present exclusively within the first person perspective of the agent, extends beyond the living body, projecting itself into physical space.

In conscious experience, the subjective "point of view" and the objects "out there in the world" can be interpreted as two directions of understanding: one inwards the conscious agent, the other outwards. In this interpretation, the "subjective" and "objective" poles of consciousness [the "noetic-noematic" divide, according to Husserl (1913)] are not conceived as Cartesian metaphysical substances, but as constructs within an organism's lived experience.

The bipolarity of the conscious mind can be found in the distinction made by Freud, on the basis of the philosophy of Schopenhauer [for an update on the contemporary influence of this philosopher, see Merker (2013)], between the Id (principle of pleasure) and Superego (principle of reality). The interplay of the two generates the concept of Ego (FREUD, 1923) and also supports a concept of "projection" (ORNSTON, 1978) in psychodynamic 
theory. Projection was conceived as a defence mechanism, which engages processes similar to those operating in normal perception.

A parallel conceptual development, also related to the Husserlian structure of consciousness and the related temporal dynamics of retention and protention [see a review of Husserl's theory of time perception in Pereira Jr. (1990)] is found in Williford et al. (2012). The authors first claim that "one typically retends not only the objects experienced, but the ways in which the objects were experienced... The reflexive structure also grounds the sense that it was an experience that happened "to me". One remembers (and retends) this very subjectivity-grounding structure. And when one says "this happened to $m e$ " one is implicitly identifying the current structure of reflexivity with the past one." (WILLIFORD et al., 2012, p. 327).

These authors also claim:

Reflexivity enters into the structure of temporality via protention. One protends or projects the upcoming episode of consciousness. One is surprised if one's expectations are violated - if a familiar melody takes a strange turn, etc. But one always protends that the experiences of the future will be one's own [...] No matter how one's experiences turn out, the projected structure of subjectivity will necessarily be there, if there is any experience at all. (WILLIFORD et al., 2012, p. 327).

The progress that is achieved with this formulation is challenged by another conceptual issue: how to explain the projection operation?

My proposed approach to the problem is to find the ground of projective operations in the context of neurobiological structures and functions. The existence of projective operations was inferred on the basis of phenomenological and related psychophysical considerations, but the investigation of the neurobiological basis of the projective operations (inward and outward) requires an interdisciplinary investigation.

I propose the concept of an extended conscious domain (ECD), characterized by a lived experience or presentation that occurs in the "egocentric space", having the subjective point of view at its center, and the world of objects "out there" as the horizon. In order to generate the ECD with its two projected poles, the subjective one (point of view) and the objective one (objects and processes out there in the world), a system containing at least two components is necessary - in the same way that, in projective geometry 
(RUDRAUF et al., 2017), in order to generate a line at least two points are necessary.

Mitterauer (2013), in this regard, proposes a "dialogical" model of the conscious mind, in which the subjective and objective poles correspond to the activity of two signaling networks in living tissue, the astroglial (subjective) and the neuronal (objective). In the same way, I conceptualize the interplay of two partners (Figure 3):

a) Feelings in living tissue, generating the sense of self as a temporal invariant pattern, or 'attractor', and

b) Mental representations carried by patterns of spiking neurons, generating the sense of the world.

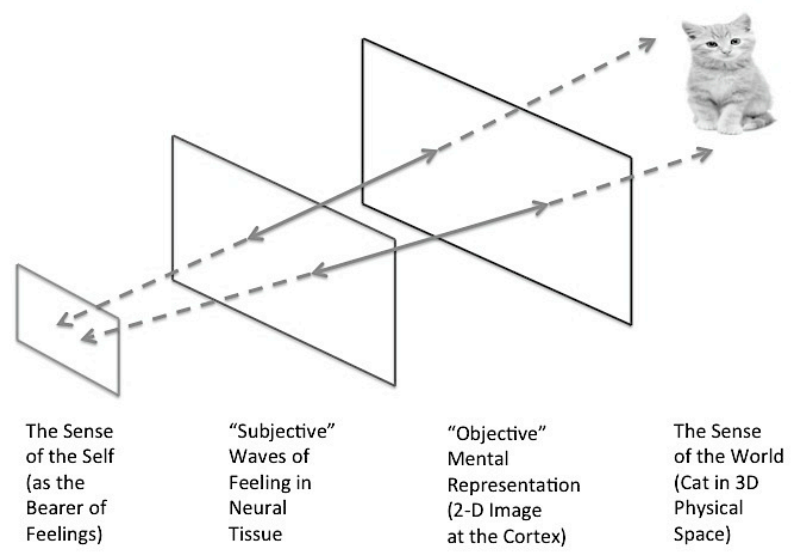

Figure 3: Extended conscious domain (containing two "virtual" poles). Two kinds of brain/mind processes (mental representations in neuronal spiking patterns and waves of feeling in living tissue) interact (continuous bidirectional arrows). From their interaction two poles are projected (dashed unidirectional arrows): the sense of self as a point of view, and the sense of the world containing $3 \mathrm{D}$ objects outside the brain/mind system (e.g., Velmans' cat).

According to the above hypothesis, the point of view is an interoceptive projective extension of subjective feeling experiences, and the objects and processes out there in the world are exteroceptive projective extensions of the 
mind/brain representations of them; in our conscious experience, we project the external world on the basis of the representations we make from signals received from stimuli.

The proposed concept of ECD is different from the concept of a representational "virtual reality" proposed by Lehar (2003) and Metzinger [(2009); see also Revonsuo (2010)], for two reasons: first, the virtual reality is composed of mental representations, while the ECD is a presentational domain. The ECD is not intrinsic to the representations; on the contrary, the representations are components of the ECD, being used to allow projective operations that generate the extended domain. Second, the ECD is not locked in the brain, but phenomenally extended to the domain of interaction with the world. Although having this aspect in common with the concept of an "extended mind" proposed by Clark (1996), the ECD is different because Clark explicitly avoids phenomenological externalism, by focusing solely on external functional relations, as with the use of technological artifacts. These functional relations extend our cognitive capabilities, but not the range of phenomenal consciousness.

Velmans $(2012,2017)$ discusses how the structure of the phenomenal mind instantiated in a living brain is affine to the structure of the world out there, referring to a "common ground of being": "Experimental psychology has made it clear that even processes that we normally think of as "conscious" for the reason that they result in conscious experiences rely on unconscious or preconscious processing that gives rise to those experiences". This approach helps to understand the unconscious generation of the consciously experienced ECD:

\footnotetext{
There is one universe (the thing-itself), with relatively differentiated parts in the form of conscious beings like ourselves, each with a unique, conscious view of the larger universe of which it is a part. In so far as we are parts of the universe that, in turn, experience the larger universe, we participate in a reflexive process whereby the universe experiences itself. (VELMANS, 2012).
}

A mathematical model of mental projection, on the basis of projective geometry and the Bayesian type of statistical inference, using conditional probability, was recently proposed by Rudrauf et al. (2017). Although the authors did not share the same references I use in the above reconstruction of 
the projective operation, their model seems to be compatible with mine. In the conclusion of the paper, they claim:

One important incentive for deriving generative models of consciousness is the possibility of using such models as mathematical tools for the development of a phenomenological psychology, based on sound formal and computational foundations. If our model contains some truth, a future formal psychological science may include the study (and the classification) of possible conscious states based on projective solutions from projective geometry in the context of processes of active inference driven by the minimization of free energy. (RUDRAUF et al., 2017, p. 129).

A comparison of the proposals would require detailed discussions that I cannot carry here; however, it should be noted that formal and computational reconstructions may be not adequate for fully describing or explaining all the phases of conscious experience that I identify in the next section.

\section{THE DYNAMICAL STRUCTURE OF THE FLOW OF CONSCIOUSNESS}

My effort towards the construction of epistemological foundations for a theory of consciousness began with the identification of a "referential nucleus" of the concept of consciousness in the context of scientific research:

Consciousness is a process that occurs in a subject (the living individual); the subject has an experience (he/she interacts with the environment, completing action-perception cycles), and the experience has reportable informational content (information patterns embodied in brain activity that can be conveyed by means of voluntary motor activity). (PEREIRA JR.; RICKE, 2009).

This preliminary concept, while indicating the kind of phenomenon that is conscious, is incomplete, because it does not describe the dynamical structure of the flow of consciousness.

Advances in cognitive, affective and action neurosciences have suggested - on the basis of the activity of the nervous system - that mental activity can occur, in biological species, in different degrees of self-awareness. The results indicate that mental activity is composed of three layers:

a) Non-conceptual features of sentience, present in the whole phylogenetic scale; 
b) Enactive capabilities that emerge with animals able of learning how to control their behaviour by means of mental representations, and

c) Conceptual features that depend on cognitive capabilities (such as our sophisticated verbal language), which develop progressively in the evolutionary process.

In the neuro-astroglial interaction model of mental activity (PEREIRA JR.; FURLAN, 2010; PEREIRA JR. et al., 2013; PEREIRA JR., 2017; PEREIRA JR. et al., 2017), feeling is a necessary component of conscious experience [as argued in Pereira Jr. (2013)]. Without feeling, all we have is non-conscious mental processing, limited to the processing of afferent information, formation of representations and activation of motor control in response to environmental stimuli. With the presence of feeling, there is a modulation of neuronal activity according to the valence attributed to the qualities of the stimulus, thus influencing the behavioral response.

The concept of feeling used in this context is broader than the common usage in the context of the neurobiology of emotions. "Feeling" here is synonymous to "experience of qualia"; for instance, to feel the taste of wine is to experience the quale of wine; to feel the smell of a rose is to experience the quale of a rose. Taking feeling as the epicentre of conscious activity, the flow of human consciousness can be analysed as a dynamic structure involving three layers and six phases, in which the previously mentioned functions (knowing, feeling and acting) are integrated.

The three layers are:

a) Non-conscious activities: They encompass physical and informational processes in the agent's body and environment, including brain physiological processes that support conscious processes, but do not appear as conscious contents;

b) Non-conceptual conscious activities: I use the term "concept" in the Platonic sense of "idea", in a theoretical framework that approaches Aristotle's philosophy. Concepts are here conceived as "mental forms" instantiated in the minds of people; minds that are not separated from their bodies and interact with a physical, social and cultural environment. An essential feature of concepts is that they can be used in logical processes. I mean by "cognition" the apprehension and combination of concepts, according to logical rules 
and using a language (verbal or imagery). Feeling comprises non-conceptual dimensions of lived experience, that is, dimensions that are not captured in logical-linguistic processes that characterize human rationality, but can be referred a posteriori by means of metaphors and/or descriptions of the types of context in which they are experienced. For example, pain is a non-conceptual experience that can be described by means of analogies (pain as a kind of "wave that runs through the body") or descriptions of the context in which it is generated (a dental caries affecting the nerve, a burn, a needle sting, etc.). "Thought by images" in Aristotle (SILVA, in press) could be considered as non-conceptual, or even as non-reflective experience, if (and only if) such images are in the sensible and/or sentimental plane; however, images can also be elevated to a conceptual plane, when they become icons (in the sense of Peirce); in this case, they lend themselves to cognitive chains, that is to say, semeiose;

c) Conceptual conscious activities: These activities encompass all conscious activities conceptually explained and recognized, by means of the use of language, images, maps and symbols, being logically linked and cabaple of being used to make rational arguments.

An analysis of the flow of consciousness reveals a structural dynamism; it is possible to identify a sequence of phases of the conscious flow. In the reconstruction of conscious experience I propose, these phases progress in the direction of growing self-awareness. The dynamic structure of consciousness is represented by a graph showing the "degree of conceptualization x degree of self-awareness" (see Figure 4). The illustrative graph is rather simplified, representing the flow of consciousness only as progressively toward greater self-awareness, but we observe in practice that the movement of consciousness can also be in the regressive sense, for example, by paying more attention to spontaneous living, when our thoughts encounter obstacles to progress in a given abstract direction.

The constitutive phases of the process are shown in the below diagram (Figure 4). 


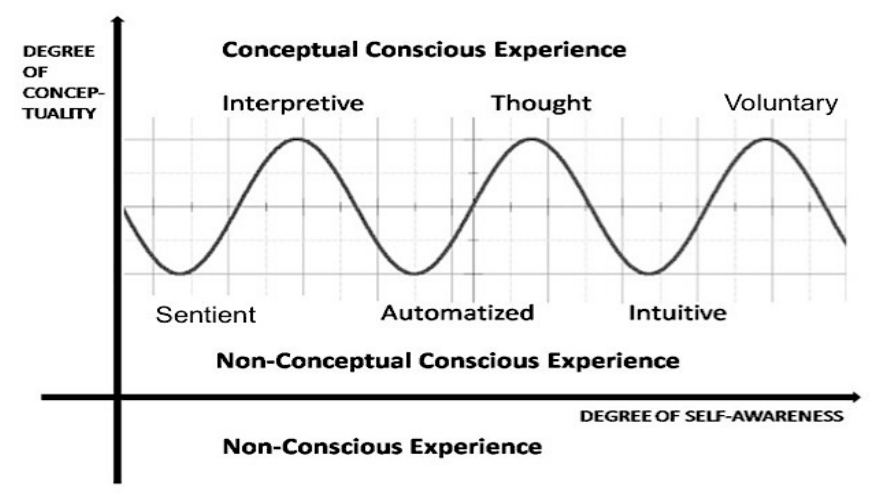

Figure 4: Analysis of the flow of consciousness. Conceptual "peaks" (interpreted, thought and voluntary) refer to conceptual conscious activities, elaborated by means of mental representations built with symbols, maps and/or images. The non-conceptual "valleys" (sentient, automatic, intuitive) refer to non-conceptual first person conscious experiences. (Original figure by Alfredo Pereira Jr).

The meaning of the phases is:

1) Sentient: This phase includes the experience of biologically induced states of consciousness [pain and pleasure, basic sensations such as hunger and thirst; see Panksepp (1996)], as well as new or surprising sensory stimuli [for a definition of sentience, see Allen and Tretsman (2016)]. In human perception this phase covers the first 300 milliseconds after exogenous or endogenous stimulation, but can be prolonged in time if the stimulus continues to be present, as in the case of chronic pain sensations. Sensations are not conceptual, in the sense that at first they are not cognitively recognized; yet, even without being conceptualized, they are consciously experienced. Cognitivist theories of consciousness may consider this phase to be non-conscious, or implying only "implicit knowledge", because in this kind of view the initial categorisation and interpretation of input is usually thought of as "pre-conscious", rather than conscious. This is in opposition to the "explicit" subsequent cognition in terms of logical categories expressed in communicable language. However, our first-person experience of feelings can also be interpreted as being not dependent on logical categorization and expression in language (which can, 
of course, occur a posteriori); and, more important for my argumentation, detailed examination of neural correlates [see, for instance, Woodruff (2017)] reveals that sentience satisfies the minimum conditions to be present in many biological species, which do not share our logical and linguistic capabilities;

2) Interpreted: In this phase, raw experience is interpreted and categorized within a cognitive framework that includes some kind of language, but not necessarily a symbolic one. We often use maps and multimodal images (visual, auditory, tactile) to interpret and categorize our sensations, resulting in mental representations of them. Emotional feelings (WANG; PEREIRA JR., 2016) are typical of this phase; for example, the sensation of pain can be generated in the first $300 \mathrm{~ms}$ after the harmful stimulus, but the emotional feeling of pain, which depends on the individual history, requires a longer time for its formation, and can be suppressed in extreme situations, as in the case of a person going through a life-threatening region, and suffering from a leg injury. She continues to walk, suppressing the emotional feeling of pain for some time; in this case, the biological survival adaptive mechanism changes the interpretation of the raw sensation, supressing the related emotion for a while;

3) Automatized: This phase corresponds to automatic formation of a chain of mental representations, in the case of familiar stimuli, and/or the activation of a learned response to unfamiliar stimuli. Conscious experiences arise in seemingly automatic fashion, in the sense that we can't under most circumstances control what we experience. Once the stimulus representation is formed, previously established connections trigger an internal response, which can also trigger a mechanical behavioural response. In the "automatic mode," we do not conceptualize the experience, but monitor it to see if the proper response is performed; for example, when cycling or swimming (and other cases that neuroscientists put under the label of "procedural memory"). For instance, driving a car while focusing conscious attention on another task (e.g., the cell phone) is a conscious automatized experience, because the road is consciously monitored; in other words, the periphery of conscious attention is not necessarily unconscious (CARRARA-AUGUSTENBORG; PEREIRA JR., 2003);

4) Thought: This phase is based on logical inferences using verbal or non-verbal language, being possibly present in all animal species able of learning a range of different responses to environment stimuli and choosing the most adequate, depending on the context. Having a conversation is usually 
regarded as one of the best examples of a non-automatic, thinking activity, for the reason that we need to respond in ways that are flexible and often novel. There are several, formal and informal, types of inference, which can be modelled in several ways, including probabilistic methods. An introspective account of the thinking phase can reveal its intrinsic structure. Introspection turns the lens of enquiry back towards itself and scrutinizes the conscious process (WEGER et al, 2018);

5) Intuitive: The intuitive phase comes after thinking, when unconscious processes irrupt into consciousness, without a direct connection with the previous phase. Intuition can be conceived as an unconscious process triggered by conscious thinking, leading to conscious manifestations of inner dispositions, without a direct connection with the results achieved in the previous thinking process; however, emergent intuitions often respond to objective questions, as in scientific discovery (MARTON et al., 1994) and economic decision (MOREWEDGE; KAHNEMAN, 2010) domains. Intuition can still be regarded as a personal conscious reaction to current lived experiences, on the basis of unconscious determinations; it is basically a dialogue of the conscious with the unconscious. In Eastern traditions, this phase is paradoxically related to the "dissolution" of the subject-object dichotomy. It is possible to solve this paradox by introducing a dynamic concept of the self, satisfying the principles formulated by Nagarjuna [see Reddy et al. (2019)];

6) Voluntary: The so-called "will" (free or not), or the desire, is a connection between the conscious episode being formed and the actions to be executed in the physical and social environment. Behaviour in response to stimulation can occur non-voluntarily, by means of reflex or automatic mechanisms. Voluntary action is mediated by connections of the central nervous system (mostly the motor cortex) with skeletal muscles. When stimuli are processed and integrated into a conscious episode, it is possible to influence behaviour towards them by means of the modulation of the activity of the pyramidal neurons of the motor cortex by tissue waves of feeling. The action control signals [as the corollary discharge; see Jeannerod (1999)] can also shape the conscious episodes we experience. This phase corresponds to the protagonism of the agent in the practical context, from our everyday desires to cultural achievements that embody the goals of a society. Selfconsciousness, resulting from the process of self-awareness, is conceived as the meta-cognitive capacity of an agent to perceive herself as the subject of the flow of consciousness and the action resulting from it. 
The identification of six phases of the flux of consciousness should help us to address central issues about the status of conscious projection.

\section{THE PHILOSOPHICAL STATUS OF PROJECTION}

The concept of projection was proposed to explain the generation of the senses of self and the world, the two poles of the informational field, upon which the dynamic structure of conscious experience is built. The domain of experience delimited by the two poles constitutes a phenomenal informational field in "egocentric space," having the subjective point of view in the center and the world of objects as horizon.

The senses of self and world are generated from the interaction of three conscious functions, knowing, feeling and acting. The issue here addressed is if the projection process is based on properly cognitive (knowing) or non-cognitive (feeling and/or acting) operations.

In the non-cognitive approach to conscious activity, the projection process is related to:

1) The emerging functions that generate the sense of self, related to the structures of the nervous system that support feelings, as studied by affective neuroscience;

2) The emerging functions that generate the sense of world, related to the structures of action-perception, as studied by the action neuroscience.

The sense of self is proposed to be a dynamic invariant in the feeling domain. The self is the entity who feels (for example, sensations of pleasure and pain); this dynamic invariant is projected into phenomenal experience as the embodied entity that constitutes the subject of conscious experiences. The sense of the world is generated as an intensional object in the domain of action, as an image of the organized set of objects to which the perceptive and enactive representations refer; the sense of the world is projected into physical space-time through efferent structures of the living body, appearing as a reality external to the brain/mind.

In the first-person perspective of the conscious agent, the projection of an information field from the CNS to the efferent pathways connected to the periphery of the body (for practical purposes, considering eye muscles as being also peripheral) can have the same phenomenal effect, as if the signal 
was actually projected to the distal regions of the egocentric space. Recent neuroscientific research has identified several extension of the CNS in the whole human body: the enteric nervous system, the cardiac nervous system, the interactions of the nervous with the endocrine and immune systems, as well as neuromuscular connections by which the brain controls our actions in the physical and social environment. The muscular effectors are connected to body sensors, forming signalling loops that extend the central nervous system to the periphery of the living body and its interfaces with the external environment. These findings add to previously known mechanisms of muscular kinaesthetic and proprioceptive sensors, which close the loops between the central nervous and the peripheral nervous systems. The looping pathways compose a broader view of the nervous system as a continuous signalling system, having a center and a periphery.

In this theoretical picture, the formation of the ECD by means of projection can be interpreted as a psychophysical process that moves from the central neural structures that instantiate feelings to the periphery of the extended nervous system and its interface with the external world. The main theoretical consequence is that the spatial location of objects is extended to the whole nervous system (beyond the brain) and its interfaces with the environment. However, the phenomenal field resulting from the processes of projection, is an information field perceived only by the individual who projects. This feature of the ECD is consistent with the hologram analogy presented by Velmans (2017). The neural mental representations that encode information about the 3D experienced realities are "in the head or brain", but the percepts are projected to the outside. He makes a question and gives a answer:

How do phenomenal cats and other phenomenal objects which are perceived to be located and extended in space get to be out there? Nothing physical is projected by the brain: there are no light rays projected through the eyes to illuminate the world, contrary to the beliefs of ancient Greek thinkers such as Empedocles. Rather, "perceptual projection" is a psychological effect produced by unconscious perceptual processing [...] A projection hologram has the interesting property that the threedimensional image it encodes is perceived to be out in space, in front of its two-dimensional surface, provided that it is viewed from an appropriate (frontal) perspective and it is illuminated by an appropriate (frontal) source of light. Viewed from any other perspective (from the side or from behind), the only information one can detect about the object is in the complex interference patterns encoded on the holographic plate. In analogous 
fashion, the information in the neural projection hologram is displayed as a visual, three-dimensional object out in space only when it is viewed from the appropriate, first person perspective of the perceiving subject [...] Viewed from any other third-person perspective, the information in S's "hologram" appears to be nothing more than neural representations in the brain (interference patterns on the plate). (VELMANS, 2017).

In this approach, the non-conceptual phases of the conscious process have relative autonomy in front of the conceptual phases, as suggested by Freud himself (FREUD, 1913) and denied by Rosenthal (2006). The neurobiological bases of the projective process are identified within the cerebral and bodily subsystems of feeling and acting, not necessarily apprehended by the (conceptually explicit) knowing system (Figure 5). Contrasting with the high order thought-type approaches, in the diagram below the existence of a sense of self and a sense of world does not depend on conceptual apprehensions of the respective concepts, which can happen a posteriori; during the experience of the projection the concepts are not conscious, but they can emerge a posteriori in the composition of the whole conscious episode.

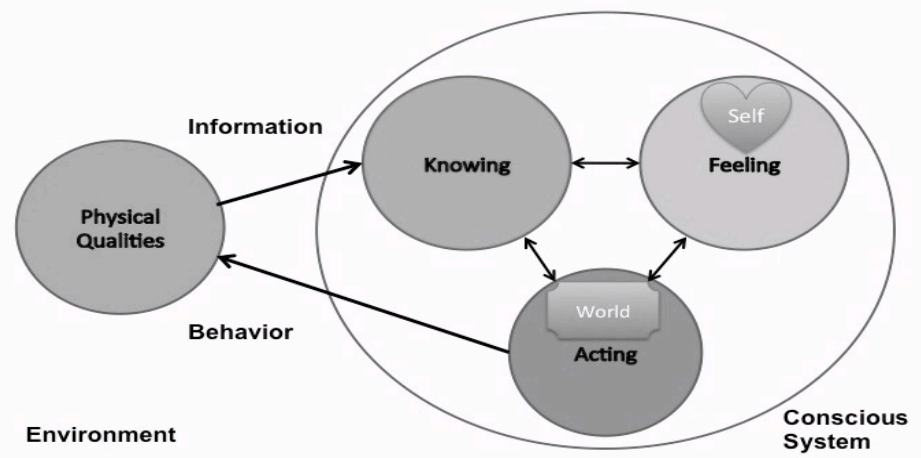

Figure 5: Non-conceptual phenomenal projection. The sense of self emerges in the sphere of feeling and the sense of the world emerges in the sphere of acting; both remain in nonconceptual phases of the flux of consciousness (or pre-reflexive, according to Merleau-Ponty, 1945). 
In the cognitivist approach, considering the arguments in this respect raised by theories of high order thought (HOT) (ROSENTHAL, 2006; LEDOUX; BROWN, 2017), the processes that generate the senses of the self and the world depend on a conceptual apprehension.

Arguing for HOT, Rosenthal (2006, p. 307) asks: "Why should verbally expressing our cognitive states be sufficient for those states to be conscious, whereas verbally expressing our emotions is not?" He correctly recognizes that: "Being conscious is an additional property that some psychological states have and others do not [...] When a mental state is conscious, one is in some way conscious of that state." Being "conscious $o f$, according to him, requires some degree of conceptualization that is not achieved by emotional processes. In Rosenthal's analysis, there are only two ways by which we can be immediately conscious of a mental state: by means of a "inner sense" (conceived within the empiricist model of sensory perception), or by means of conceptual thinking:

\begin{abstract}
The only qualities that figure when we are aware of our mental states are the qualities of the states we are aware of, not qualities that pertain to our awareness of those states. When we see something consciously, for example, the only relevant qualities are the colour qualities of our visual sensations [...] For these and other reasons, we must reject the idea that, when our thoughts, feelings, and sensations are conscious, we are perceptually aware of those states. Still, we are conscious of them somehow. The only alternative is that we have thoughts about these states. (ROSENTHAL, 2006, p. 311).
\end{abstract}

In the conceptual consciousness conception, the results of the projective process become conscious only when expressed at the cognitive sphere (Figure 6), by means of a "high-order thought". In the neurobiologically based proposal of LeDoux and Brown (2017), the neocortex is identified as the integrative center of the mammalian brain where conscious thoughts are formed. In this approach, both the feelings/emotions and the enactive spatiotemporal representations of the world, formed in other circuits and regions of the nervous system, would have to be cognitively accessed, conceptually formulated and referred to the system itself, to become conscious. All mental representation supported by different parts of the nervous system depend on conceptual thinking to become effectively conscious. 


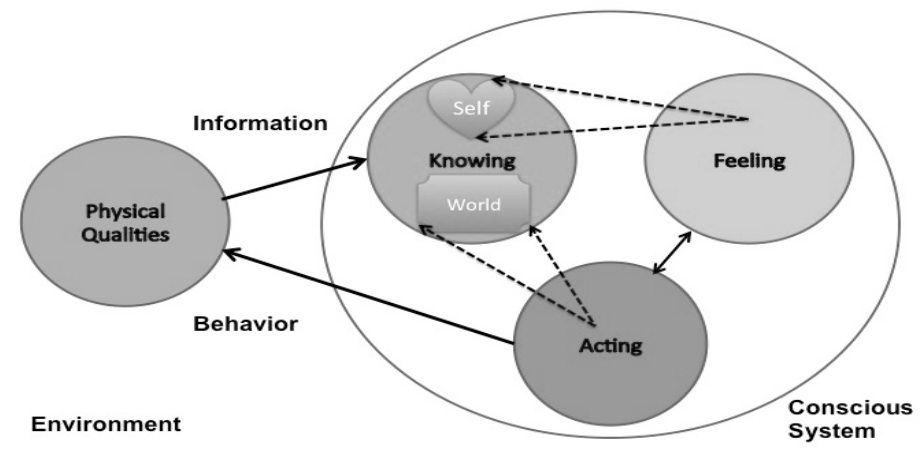

Figure 6: Conceptual consciousness. In this approach, the projection of the senses of the self and the world, and its integration into an informational field, begins in the spheres of feeling and acting, but is only completed when projected in the cognitive sphere by means of a "high order thinking" or "meta-cognition" (in the sense of forming knowledge about one's own consciousness).

A way out Rosenthal's dilemma of "empiricism against rationalism" can be found (besides Freud's metapsychology) in contemporary affective and enactive neurosciences, which have revealed the possibility of non-conceptual feeling and acting experiences, corresponding to the valleys of the flow of consciousness in Figure 4. However, any attempt to solve this issue at this moment is premature, because we are just beginning to formulate the right questions. In this regard, the existence of two alternatives for the interpretation of the projection process is beneficial for our philosophical and scientific investigations.

\section{TeSTING THE HYPOTHESIS}

How can we discuss and test the perceptual projection hypothesis and its ontological status (i.e., being based on affective and enactive processing, or being mostly cognitive)? To do so, we will resort to an important discussion in the context of neurosciences and the philosophy of the human mind, having as the main protagonists Ned Block and David Rosenthal, with incursions in philosophical psychology and in neuroscience. 
Block $(1995,2008,2011)$ assumed a position in favour of the existence of non-cognitive phenomenal consciousness, which would not depend on a posteriori cognition to exist: "My first conclusion then is that the overlap of the neural machinery of cognitive access and the neural machinery of phenomenology can be empirically investigated. Second, there is evidence that the latter does not include the former." (BLOCK, 2008, p. 498). Block's approach points to the possibility of non-conceptual phenomenal consciousness, which would include - according to our hypothesis - the projection process. This type of conscious activity has the capacity of forming memories that can be conceptually rescued and reported a posteriori.

The latter stages in the formation of a conscious episode influence how we experience the representations formed in the earlier stages, as shown, for instance, by results of experiments with backwards masking [see examples and discussion in Pereira Jr. (2017)]. Considering that later stages can influence representations of input, a method for testing Block and Rosenthal's proposals was suggested by Brown (2014), himself advocate of a HOT-type approach:

If phenomenal consciousness depends in any way on high order cognitive functioning, then we must be able to altering the conscious experience of the subjects by interfering with areas of the brain believed to be involved in higher order cognition while leaving unprocessed first-order processing. (BROWN, 2014).

This suggestion is important for the testing of the various theories of consciousness.

Affective neuroscience [as formulated by Panksepp (1997)] can explain the biological basis of emotions and feelings, and action neuroscience (JEANNEROD, 1999) can explain the schemes we use to control behaviour, but at first sight they do not seem adequate to explain the two components of the phenomenal domain, the senses of self and of the world. The projection process operates as a bridge principle to connect these neural systems with the phenomenal field. If we interpret projection as a higher order conceptual or meta-cognitive operation, we should agree with David Rosenthal's HOT, as argued by Brown; if we interpret the projection as a non-conceptual operation, the decision should be given to Block.

However, agreement with Block does not imply accepting his distinction between phenomenal and access consciousness (BLOCK, 
1995). The issue currently discussed under the name of "overflow" can be conceived as independent from the distinction between phenomenal and access consciousness. In Block's view (BLOCK, 2011), "overflow" means that phenomenal consciousness is broader than access consciousness. However, if there is not such a distinction, and all consciousness is assumed to be phenomenal, the formulation of the problem is different. In this case, the discussion is about the six phases (sentient, interpretive, automatic, thought, intuitive and voluntary; see Figure 4) within phenomenal consciousness. The preferred hypothesis is that the senses of self and world do not depend on thinking; they are more related to other phases of the flow of consciousness (Figure 5). The alternative hypothesis, based on the proposals of Rosenthal, Brown and LeDoux, considers the conceptual thought phase central and necessary for any conscious experience (Figure 6).

I identify eight ways of discussing and testing the dependence of phenomenal consciousness on higher order cognitive operation; these different ways will be better elucidated and discussed in the course of our future research:

1) In Neurophenomenology: When searching for the cerebral correlates of first person experiences, it is interesting to check with adequate experimental planning whether the areas related to the HOT processes would necessarily be activated when people non-verbally report their apprehension of the sense of the self and the sense of the world. In first-person reports of effects of neuropathology (traumatic or non-traumatic neurological lesions), sensory impairment or induced deprivation of different intensities and modalities, for example blindness, amblyopia, deafness, it should be possible to dissociate properly cognitive effects from affective and enactive components;

2) In Freudian metapsychology: One could alter affective experiences by means of a conceptual rationalization of the unconscious factors involved in the projective process, as in psychodynamics. Rosenthal (2006, p. 307) notes that "according to psychoanalytic theory, the beneficial effect of treatment results largely from unconscious states' coming to be conscious"; however, "simply expressing affective states in words cannot ensure that those states will be conscious. One must go further and explicitly report or describe those states" by means of a conceptual expression (ROSENTHAL, 2006, p. 307-308). The projective operation, in this case consisting of the conceptual expression of affects, can be tested by means of looking for exceptions to the rule, as in the cases of parapraxis discussed by Rosenthal (2006); 
3) In Hypnosis research: Hypnotic suggestion, affecting meta-cognitive processes, may also affect sensory and/or affective experiences. There is an ongoing debate regarding the processing stage at which suggestion blocks information from breaching consciousness. Highly suggestible individuals have a metacognitive deficit pertaining to intentions and/or to the interoceptive and environmental signals relating to sense of agency. There is evidence for a fairly selective deficit (TERHUNE; HEDMAN, 2017). It would certainly be interesting to consider the processing stage where disrupted awareness emerges;

4) In Pharmacological psychiatry: In this field we find many evidences of effects of psychoactive drugs that selectively affect cognitive processes, affective processes, and motor processes [see a review in Wang and Pereira Jr. (2016)]; one can then discuss the degrees of dependence between such processes;

5) In Brain stimulation therapies (electric, magnetic): In this area of experimental research, it can be verified whether the stimulation of a specific area of cognition, affection or motor control, can have direct and/or secondary effects on another area(s). In regard to the projection process, do changes in the experienced structure of the self and the world correlate with stimulation of cognitive, affective and/or motor areas?;

6) In the Epistemology of meditation: One can discuss, from reports of meditators, and eventually also using records of EEG patterns of brain activity (regarding the paths and phases of the meditation process), whether or not they correspond to the dynamic structure illustrated in Figure 4;

7) In Psychophysics: There is a rich literature on the mechanisms involved in spatial perception; for example, on object size and perceived distance [see Silva et al. (2006)]. There is also a literature on the ways the perception of space can be altered (VELMANS, 2009, p. 162-164) and on the effect of automatic unconscious operations, based on the action system, determining features of conscious perception (BHANGAL et al., 2018);

8) In Systematic introspection: Using the method of Weger et al. (2018), one can evaluate the determinations of thought and feeling in conscious dynamics. 


\section{Concluding Remarks}

In this paper, I raised an argument in favour of the projective theory of consciousness providing a link between the neurosciences and the domain of phenomenal consciousness. The nature of the projective process is still not well defined; it may be the result of the integration of distributed conscious processes in the nervous system, or a properly conceptual process based on the cognitive circuits embodied in the mammalian neo-cortex. A theoretical choice between the two alternatives is related to the concept of consciousness that is assumed, and to conjectures about the existence of conscious experiences in a diversity of species along the phylogenetic scale, most of which do not have human cognitive capabilities. At the present stage of investigation of conscious activity, the main conclusion is that the hypothesis of projection is amenable to philosophical and scientific treatments. The discussion of the concept of perceptual projection and its relations with related approaches (as predictive coding), and the ways of empirical investigation, are rich and promising. ${ }^{2}$

PEREIRA JR., A. A teoria projetiva da consciência: da neurociência à psicologia filosófica. Trans/Form/Ação, Marília, v. 41, p. 199-232, 2018. Edição Especial.

Resumo: O desenvolvimento de áreas interdisciplinares das neurociências (cognitiva, afetiva e da ação), contribui para a identificação das bases neurobiológicas da experiência consciente. A estrutura intrínseca da experiência consciente foi filosoficamente concebida há um século como consistindo de um pólo subjetivo, o portador de experiências, e um pólo objetivo, composto dos conteúdos experimentados. Em formulaçōes mais recentes, Thomas Nagel refere-se a um "ponto de vista", no qual experiências qualitativas são ancoradas, enquanto Max Velmans entende que o conteúdo fenomenal é composto de representaçóes mentais "projetadas" para o espaço externo ao cérebro que as constrói. Na psicologia freudiana, a mente consciente contém uma tensão entre o Id e o Ego. Como relacionar esta estrutura bipolar com os resultados da neurociência? Proponho a noção de projeção (também utilizada por Williford et al., 2012) como princípio-ponte, conectando os sistemas neurobiológicos do saber, sentir e agir com a estrutura bipolar. O processo projetivo é considerado responsável pela geraçáo do sentido do eu e do sentido do mundo, compondo um campo fenomenal informacional gerado pelo sistema nervoso e vivenciado na perspectiva da primeira pessoa. Após apresentar a hipótese projetiva, discuto seu status filosófico, relacionando-o às abordagens fenomenológicas, à teoria do pensamento de ordem superior e ao modelo matemático da projeçấo. Oito maneiras de testar o status da hipótese projetiva são brevemente mencionadas.

Palavras-chave: Projeção. Consciência. Cognitivo. Não conceitual. Sentimento.

2 I am grateful to FAPESP (São Paulo State Research Funding Agency) for support of this research; to Drs. Max Velmans and Chris Nunn, for critical comments; Dr. David Rosenthal, for clarifications about HOT; and Drs. Kenneth Williford, Claudia Carrara-Augustenborg, Michael Woodruff, Manuel Moreira da Silva and Enidio Ilario, for suggestions and encouraging comments. 


\section{REFERENCES}

ALLEN, C.; TRESTMAN, M. Animal consciousness. In: ZALTA, E. N. (ed.). The stanford encyclopedia of philosophy. Winter Edition. Stanford, USA: CSLI Stanford University 2016. Avaliable on: <https://plato.stanford.edu/entries/consciousnessanimal/>. Access in: 16 jun.2018.

BAARS, B. J. A cognitive theory of consciousness. New York: Cambridge University Press, 1988.

BARRETT, L. F. The theory of constructed emotion: an active inference account of interoception and categorization. Social Cognitive and Affective Neuroscience, v. 12, n. 47, p. 1-23, 2017.

BARRETT, L. F.; RUSSELL, J. A. Independence and bipolarity in the structure of current affect. Journal of Personality and Social Psychology, v. 74, n. 4, p. 967-984, 1998.

BHANGAL, S. et al. Involuntary entry into consciousness from the activation of sets: object counting and color naming. Front Psychol. v. 9, p. 1017, 2018. doi: 10.3389/ fpsyg.2018.01017. Avaliable on: <https://www.ncbi.nlm.nih.gov/pmc/articles/ PMC6021744/> . Access in: 16 jun.2018.

BLOCK, N. On a confusion about a function of consciousness. Behavioral and Brain Sciences, v. 18, n. 2, p. 227-287, 1995.

. Consciousness, accessibility, and the mesh between psychology and neuroscience. Behavioral and Brain Sciences, v. 30, n. 5-6, p. 481-499; discussion 499548, 2008.

. Perceptual consciousness overflows cognitive access. Trends Cogn Sci., v. 15, n. 12, p. 567-575, 2011.

BOURGET, D.; MENDELOVICI, A. Phenomenal intentionality. In: ZALTA, E. N. (ed.). The Stanford Encyclopedia of Philosophy, 2017. Available on: <https://plato.stanford. edu/archives/spr2017/entries/phenomenal-intentionality/>. Access in: 20 ago.2018.

BROWN, R. Consciousness doesn't overflow cognition. Frontiers in Psychology, v. 5, p. 1399, 2014. doi: 10.3389/fpsyg.2014.01399. Avaliable on: <https://www.ncbi.nlm. nih.gov/pmc/articles/PMC4255486/>. Access in: 16 ago.2018.

CARRARA-AUGUSTENBORG, C.; PEREIRA JR., A. Brain endogenous feedback and degrees of consciousness. In: CAVANNA, A. E.; NANI, A. (ed.). Consciousness: states, mechanisms and disorders. New York: Nova Science, 2012.

CLARK, A. Being there: putting brain, body and world together again. Cambridge, MA: The MIT Press, 1996.

CRICK, F. The astonishing hypothesis: the scientific search for the soul. New York: Charles Scribner's; Maxwell McMillan, 1994. 
DAMASIO, A. The feeling of what happens: body and emotion in the making of consciousness. New York: Harcourt, 2000.

DEHAENE, S.; CHANGEUX, J. P. Experimental and theoretical approaches to conscious processing. Neuron, v. 70, n. 2, p. 200-227, 2011.

EDELMAN, G. M. The remembered present: a biological theory of consciousness. New York, NY, US: Basic Books, 1989.

FERNANDES DE LIMA, V. M.; PEREIRA JR., A. The plastic glial synaptic dynamics within the neuropil: a self-organizing system composed of polyelectrolytes in phase transition, Neural Plasticity, ID. 7192427, 2016. DOI:10.1155/2016/7192427. Avaliable on: <https:/www.hindawi.com/journals/np/2016/7192427/> . Access in: 10 ago.2018.

FREUD, S. The Ego and the Id. London: Hogarth, 1923. (Standard Edition. V. 19).

GAZZANIGA, M. S. (ed.). The cognitive neurosciences. Cambridge: MIT Press, 1993.

HARNAD, S. Doing, feeling, meaning and explaining. 2011. Available on: <http://www. academia.edu/2747688/Doing_Feeling_Meaning_And_Explaining $>$. Access in: 10 ago. 2018.

HEIDEGGER, M. Being and time. Translated by J. Macquarrie and E. Robinson. Oxford: Blackwell, 1962.

HUSSERL, E. Ideas: general introduction to pure phenomenology. Translation by F. Kersten. Dordrecht: Kluwer Academic, 1913.

. Meditations cartesiennes: introduction à la phenomenologie. Translation by G.

Peiffer and E. Levinas. Paris: Vrin, 1947.

JEANNEROD, M. The cognitive neuroscience of action, Oxford: Blackwell, 1997.

$\mathrm{KOCH}, \mathrm{C}$. The quest for consciousness: a neurobiological approach. Englewood: Roberts \& Company, 2003.

LEDOUX, J. E.; BROWN, R. A higher-order theory of emotional consciousness. Proc. Natl. Acad. Sci. U.S.A., v. 114, n. 10, p. E2016-E2025, 2017. doi:10.1073/ pnas. 1619316114.

LEHAR, S. Gestalt isomorphism and the primacy of subjective conscious experience: a gestalt bubble model. Behavioral \& Brain Sciences, v. 26, n. 4, p. 375-444, 2003.

MARTON, F.; FENSHAM, P.; CHAIKLIN, S. A nobel's eye view of scientific intuition: discussions with the Nobel prize winners in physics, chemistry and medicine. International Journal of Science Education, v. 16, n. 4, p. 457-473, 1994.

MCLEAN, P.D. The triune brain in evolution. New York: Plenum Press, 1990.

MERLEAU-PONTY, M. Phenomenologie de la perception. Paris: Gallimard, 1945. 
METZINGER, T. The ego tunnel: the science of the mind and the myth of the self. New York: Basic Books, 2009.

MITTERAUER, B. The proemial synapse: consciousness-generating glial-neuronal units. In: PEREIRA JR., A.; LEHMANN, D. (ed.). The unity of mind, brain and world: current perspectives on a science of consciousness. Cambridge-UK: Cambridge University Press, 2013.

MOREWEDGE, C. K.; KAHNEMAN, D. Associative processes in intuitive judgment. Trends in cognitive sciences, v. 14, n. 10, p. 435-40, 2010.

MORSELLA, E. The function of phenomenal states: supramodular interaction theory. Psychol. Rev., v. 112, n. 4, p. 1000-1021, 2005.

NAGEL, T. What is it like to be a bat? Philos. Rev., v. 83, n. 4, p. 435-450, 1974. Avaliable on: <http://faculty.arts.ubc.ca/maydede/mind/Nagel_ Whatisitliketobeabat.pdf>. Access in: 16 ago.2018.

. The objective self. In: GINET, C.; SHOEMAKER, S. (org.). Knowledge and mind. Oxford: Oxford University Press, 1983. p. 211-232.

NAGEL, T. The view from nowhere. Oxford: Oxford Univ. Press, 1986.

NORTHOFF, G. Neuro-philosophy and the healthy mind: learning from the Unwell Brain. New York; London: W.W. Norton, 2016.

ORNSTON, D. On projection: a study of Freud's usage. The Psychoanalytic Study of the Child, v. 33, p. 117-166, 1978.

PANKSEPP, J. Affective neuroscience: the foundations of human and animal emotions. New York: Oxford University Press, 1998.

. Affective consciousness: core emotional feelings in animals and humans.

Consciousness and Cognition, v. 14, n. 1, p. 30-80, 2005.

PEREIRA JR. A. A percepção do tempo em Husserl. Trans/Form/Ação, v. 13, p.73-83, 1990.

. Perceptual information integration: hypothetical role of astrocytes. Cognitive Computation, v. 4, n. 1, p. 51-62, 2012.

. Triple-aspect monism: a conceptual framework for the science of human consciousness. In: PEREIRA JR., A.; LEHMANN, D. (ed.). The unity of mind, brain and world: current perspectives on a science of consciousness. Cambridge, UK: Cambridge University Press, 2013. p. 299-337.

- Triple-aspect monism: physiological, mental unconscious and conscious aspects of brain activity. Journal of Integrative Neuroscience, v. 13, n. 2, p. 201-227, 2014. 
. Astroglial hydro-ionic waves guided by the extracellular matrix: an exploratory model. Journal of Integrative Neuroscience, v. 16, n. 1, p. 1-16, 2017. doi: 10.3233/JIN160003.

.; ALMADA, L. F. Conceptual spaces and consciousness research: integrating cognitive and affective processes. Int J Mach Conscious, v. 3, n. 1, p. 127-143, 2011.

.; BARROS, R. F.; SANTOS, R. P. The calcium wave model of the perceptionaction cycle: evidence from semantic relevance in memory experiments. Frontiers in Psychology, v. 4, p. 252, 2013. doi: 10.3389/fpsyg.2013.00252.

.; FOZ, F. B.; ROCHA, A. F. Cortical potentials and quantum-LikeWaves in the generation of conscious episodes. Quantum Biosystems, v. 6, n. 1, p. 9-20, 2015.

.; FOZ, F. B.; ROCHA, A. F. The dynamical signature of conscious processing: from modality-specific percepts to complex episodes. Psychology of Consciousness, v. 4, n. 2, p. 230-247, 2017.

; FURLAN, F. A. On the role of synchrony for neuron-astrocyte interactions and perceptual conscious processing. Journal of Biological Physics, v. 35, n. 4, p. 465- 481, 2009.

; FURLAN, F. A. Astrocytes and human cognition: modeling information integration and modulation of neuronal activity. Progress in Neurobiology, v. 92, n. 3, p. 405-420, 2010.

.; RICKE, H. What is consciousness? Towards a preliminary definition. Journal of Consciousness Studies, v. 16, n. 5: p. 28-45, 2009.

. et al. Understanding consciousness: a collaborative attempt to elucidate contemporary theories. Journal of Consciousness Studies, v. 17, n. 5/6, p. 213- 219, 2010.

.; VIMAL, R.; PREGNOLATO, M. Can qualitative physics solve the hard problem? In: POZNANSKI, R.; TUSZINSKI, J.; FEINBERG, T. (ed.). Biophysics of Consciousness: a foundational approach. Singapore: World Scientific, 2016. p. 149-187.

. et al. Consciousness and cosmos: building an ontological framework. Journal of Consciousness Studies, v. 25, n. 3/4, p. 181-205, 2018.

PREGNOLATO, M.; DAMIANI, G.; PEREIRA JR., A. Patterns of calcium signaling: a link between chronic emotions and cancer. J Integr Neurosci., v. 16, n. 1(supl.), p. S43-S63, 2017.

REDDY, S. K. et al. The 'self' aspects: the sense of existence, identification, and location. Integrative Psychological \& Behavioral Science, 2019. (Accepted in September 2018).

REVONSUO, A. Consciousness: The science of subjectivity. New York: Psychology Press, 2010.

ROCHA, A. F.; PEREIRA JR, A.; MASSAD, E. The brain: from fuzzy grammar to quantum computing. Berlin, Germany: Springer, 2005. 
ROSENTHAL, D. M. Consciousness and its expression. In: ROSENTHAL, D. M. Consciousness and Mind. USA: Oxford University Press, 2006. p. 307-319.

RUDRAUF, D. et al. A mathematical model of embodied consciousness. J Theor Biol., v. 428, p. 106-131, 2017. doi: 10.1016/j.jtbi.2017.05.032.

SILVA, J. A. et al. Acerca da métrica da percepção do espaço visual. Arq. Bras. Oftalmol., v. 69, n. 1, p.127-135, 2006.

SILVA, M. M. A concep̧̧ão aristotélica do pensar em imagens. Preprint. No prelo.

STUSS, D. T.; ESKES, G. A.; FOSTER, J. K. Experimental neuropsychological studies of frontal lobe functions. In: BOLLER, F.; GRAFFMAN, J. (ed.). Handbook of Neuropsychology. New York: Elsevier Science, 1994. V. 9.

TERHUNE, D. B.; HEDMAN, L. R. A. Metacognition of agency is reduced in high hypnotic suggestibility. Cognition, v. 168, p. 176-181, 2017.

TONONI, G. et al. Integrated information theory: from consciousness to its physical substrate. Nat. Rev. Neurosci., v. 17, n. 7, p. 450-461, 2016.

TYE, M. Ten problems of consciousness. Cambridge: The MIT Press, 1995.

. Representationalism and the transparency of experience. Nồs, v. 36, n 1, p. $137-51,2002$.

VARELA, F. J. Neurophenomenology: a methodological remedy for the hard problem. Journal of Consciousness Studies, v. 3, n. 4, p. 330-349, 1996.

.; SHEAR, J The view from within: first-person approaches to the study of consciousness. Exeter: Imprint Academic, 1999.

VELMANS, M. Consciousness, brain and the physical world. Philosophical Psychology, v. 3, n. 1, p. 77-99, 1990.

. A reflexive science of consciousness. In: BOCK, G.; MARSH, J. (ed.).

Experimental and theoretical studies of consciousness. Chichester: John Wiley, 1993. p. 8199.

. Understanding consciousness. 2nd. ed. London: Routledge, 2009.

Reflexive monism: psychophysical relations among mind, matter and consciousness. Journal of Consciousness Studies, v. 19, n. 9-10, p. 143-165, 2012. Available on: <https://www.researchgate.net/publication/258208689_Reflexive_Monism_ Psychophysical_Relations_among_Mind_Matter_and_Consciousness $>$. Access in: 16 ago. 2018.

. What and where are conscious experiences? Dualism, reductionism and reflexive monism. In: ALMQVIST, K.; HAAG, A. (ed.). The return of consciousness: a new science on old questions. Stockholm: Axel and Margaret Axson Johnson Foundation, 2017. p. 125-143.Avaliable on: <https://www.researchgate.net/publication/312596560_ 
What_and_where_are_conscious_experiences_Dualism_reductionism_and_ reflexive_monism>. Access in: 16 ago.2018.

WANG, F.; PEREIRA JR., A. Neuromodulation, emotional feelings and affective disorders. Mens Sana Monographs, v. 14, n. 1, p. 5-29, 2016.

WEGER, U.; WAGEMANN, J.; MEYER, A. Introspection in psychology: its contribution to theory and method in memory research. European Psychologist, 2018. Available on: <https://doi.org/10.1027/1016-9040/a000296>. Access in: 10 ago.2018.

WILLIFORD, K.; RUDRAUF, D.; LANDINI, G. The paradoxes of subjectivity and the projective structure of consciousness. In: MIGUENS, S.; PREYER, G. (ed.). Consciousness and subjectivity. Frankfurt a. M.: Ontos, 2012. p. 47-321.

WITTGENSTEIN, L. On certainty. Edited by G. E. M. Anscombe and G. H. von Wright. Oxford: Blackwell, 1969.

WOODRUFF, M. L. Consciousness in teleosts: there is something it feels like to be a fish. Animal Sentience, v. 13, n. 1, 2017.

WURTZ, R. H. Corollary discharge in primate vision. Scholarpedia, v. 8, n. 10, p. 12335, 2013.

ZAHAVI, D. Consciouness and (minimal) selfhood: getting clearer on for-me-ness and mineness. In: KRIEGEL, U. (ed.). The Oxford Handbook of the Philosophy of Consciousness. Oxford University Press, 2017.

Recebido: $15 / 11 / 2018$

Aceito: $15 / 11 / 2018$ 
PEREIRA JR., A 